\title{
Identification of Pm24, Pm35 and Pm37 in thirteen Egyptian bread wheat cultivars using SSR markers
}

\section{Identificação de $P m 24, P m 35$ e Pm37 em treze egípcios cultivares de trigo utilizando marcadores microssatélites}

\author{
Hassan Mahmoud Emara ${ }^{1 *}$, Ayman Feisal Omar², Moustafa Mahmoud El-Shamy³, Mona Elsaid Mohamed ${ }^{3}$ \\ 'Botany Department, Faculty of Science, Benha University, Egypt \\ ${ }^{2}$ Department of Botany, Plant Pathology \& Biotechnology Laboratory, Faculty of Agriculture, Kafrelsheikh University, Egypt \\ ${ }^{3}$ Wheat Diseases Research Department, Plant Diseases Research Institute, ARC, Giza, Egypt \\ *Corresponding author: hassanmemara@yahoo.com \\ Received in october 6, 2015 and approved in january 8, 2016
}

\begin{abstract}
Powdery mildew of wheat (Triticum spp.) caused by Blumeria graminis f.sp. tritici (DC) E.O. Speer Em. Marchal is one of the most important bread wheat diseases in Egypt. All the Egyptian common bread wheat cultivars are susceptible to that disease at seedling and adult stages. Breeding of resistant cultivars is the most economical and environmentally safe method to eliminate the disease and reduce crop losses. Combinations of two or more effective resistance genes may lead to better, more durable resistance to that disease. Eight $P m$ genes i.e. $P m 2, P m 6, P m 12, P m 16, P m 24, P m 35, P m 36$ and $P m 37$ out of 21 powdery mildew monogenic wheat lines $(P m)$ were resistant to 42 individual isolates of powdery mildew collected from different governorates in the Nile Delta area, Egypt, at seedling and adult stages. Only four DNA specific SSR markers (Xgwm337, Xcfd7 linked to Pm24, Pm35 and Xgwm332, Xwmc790) linked to Pm37 resistance genes were selected to detect these genes in 13 Egyptian common bread wheat cultivars. This study reveals the absence of $P m 24, P m 35$ and $P m 37$ in all the 13 Egyptian bread wheat cultivars. These results gave evidence that the Egyptian cultivars are not having resistance genes and need to further incorporate one, two or more resistant genes in a single genotype as all commercial cultivars defeated by the pathogen.
\end{abstract}

Index terms: Powdery mildew; genetic control; DNA; molecular markers.

\begin{abstract}
RESUMO
O oídio causado por Blumeria graminis f.sp. tritici (DC) E.O. Speer Em. Marchal é uma das doenças mais importantes do trigo (Triticum spp.) no Egito. Todos os cultivares de trigo egípcios são suscetíveis a essa doença tanto na fase jovem quanto em plantas adultas. 0 melhoramento genético de cultivares resistentes é o método mais econômico e ambientalmente seguro para eliminar a doença e reduzir as perdas de colheita. As combinações de dois ou mais genes de resistência podem conduzir a uma maior resistência a essa doença. Oito $P m$ genes ( $P m 2$, Pm6, Pm12, Pm16, Pm24, Pm35, Pm36 e Pm37) entre 21 linhagens monogênicas de trigo foram resistentes a 42 isolados individuais de oídio coletados em diferentes províncias na área do Delta do Nilo, no Egito, em plantas jovens e adultas. Quatro marcadores microssatélites de DNA específicos, (Xgwm337, Xcfd7 ligada a Pm24, Pm35 e Xgwm332, Xwmc790) ligados a genes de resistência $P m 37$ foram selecionados para detectar esses genes em 13 cultivares de trigo egípcios. Nosso estudo revela a ausência de $P m 24, P m 35$ e Pm37 em todos os 13 cultivares de trigo egípcios. Estes resultados demonstram que os cultivares egípcios não possuem genes de resistência e necessitam incorporar um, dois ou mais genes resistentes num genótipo e nos cultivares comerciais suscetíveis ao patógeno.
\end{abstract}

Termos para indexação: Oídio; controle genético; DNA; marcadores moleculares.

\section{INTRODUCTION}

Powdery mildew of wheat, caused by the fungus (Blumeria graminis f. sp. tritici Marchal), is a common disease that spread all over the world. In Egypt, the disease appeared in the last few years with high disease severities on most of the common wheat cultivars especially in the Gharbia governorate, Nile Delta, Egypt. Powdery mildew can lead to reduction of wheat spike and grain number resulting in a yield loss e.g. 10\% - 62\% in Brazil (Costamilan, 2005),
48\% in Canada (Everts; Leath, 1992; Maxwell et al., 2009), $10-18 \%$ in Egypt (El-Shamy et al., 2012) and $10-30 \%$ in China (Huang et al., 2013). Utilization of resistant cultivars is the most economical and environmental-friendly approach to control the disease, enabling reductions in fungicide use. A diversified and effective resistant gene sources must be the basis of breeding wheat cultivars with powdery mildew resistance. Development of resistant germplasm to powdery mildew is based on interspecific hybridization and backcrossing (Murphy; Navarro; Leath, 2002; Navarro et 
al., 2000). To date, 61 powdery mildew resistance genes, mapped to 43 loci (McIntosh; Yamazaki; Dubcovsky, 2008; He et al., 2009; Hua et al., 2009; Li; Fang; Zhang, 2009; Luo et al., 2009) have been identified and formally catalogued in wheat. However, some of the genes, derived from wild relatives, are difficult to use in wheat breeding because of linkage drag (Hospital, 2001). Consequently, there are only a limited numbers of effective race-specific resistance genes available for use by breeders. The following genes have been primarily used in development of powdery mildew resistant cultivars i.e. $P m 2, P m 3, P m 4 a, P m 4 b, P m 6$ and $P m 8$. More recently described resistance genes including $P m 13$, $P m 21$, and $P m 24$ were introduced in breeding programs in order to provide more diversity (Cheng et al., 2003; Sang et al., 2006). Molecular identification of specific DNA sequences can be used to identify the presence or absence of wheat powdery mildew $(\mathrm{Pm})$ genes in wheat cultivars, their chromosomal location, the number of genes, and the way in which they are transmitted to progeny (Chen and Chelkowski, 1999).

The availability of molecular markers, used for identifying, mapping, and cloning powdery mildew resistance genes, has greatly enhanced the development of molecular breeding. Currently, microsatellites [simple sequence repeats (SSR)] are the preferred type of molecular marker for marker-assisted selection (MAS) in wheat breeding. Molecular markers are known to be useful in the process of detection of the disease resistance genes, especially in genotypes where the genetic back ground has not been clarified as is the case for most commercial cultivars. The genes Pm24, $P m 35$, and $P m 37$ were approved to be effective genes against the disease in the regions with similar ecological condition as Egypt in the world (Huang et al., 2000; Langridge et al., 2001; Miranda et al., 2007; Perugini et al., 2008). Therefore, this study was conducted to identify those powdery mildew resistance genes i.e. $P m 24, P m 35$ and $P m 37$ in 13 registered Egyptian bread wheat cultivars using SSR markers under the Egyptian conditions.

\section{MATERIAL AND METHODS}

\section{Plant materials}

Thirteen Egyptian bread wheat cultivars common in Egypt obtained from the National Wheat Program, Crop Research Institute, ARC, Giza (Table 1) and twenty-one powdery mildew host differentials resistant to the powdery mildew and the susceptible check cultivar chancellor were used in this study (Table 2). The monogenic wheat lines were kindly provided by Dr. Christina Cowger (USDAARS, North Carolina State University). Seeds of each line were sown in individual plastic pots $(10 \mathrm{~cm}$ diameter $)$ containing soil mixed with peat moss $(1: 1 \mathrm{w}: \mathrm{w})$ under greenhouse conditions.

Table 1: Bread wheat cultivars and their pedigree used in this study.

\begin{tabular}{cl}
\hline $\begin{array}{c}\text { Cultivars/ Pm } \\
\text { genes }\end{array}$ & \multicolumn{1}{c}{ Pedigree } \\
\hline Gemmeiza-7 & CMH74A.360/5x//Seri82/3/Agent CGM4611-2GM-3GM-1GM-0GM. \\
Gemmeiza-10 & Maya 74"S"/ On// 1160-174/3/ Bb/4/ Chal "S"/5/Ctow. \\
Gemmeiza-11 & BUC"S"/ Kvz"S"// 7c/ Seri 82 /3/Giza 168/ Sakha 61 GM7892-2GM-1GM- 0 GM. \\
Gemmeizas-12 OTS/3/ SARA/ THB// vee-CMss97Y0027S-5Y-010M-010Y-010M-2Y-1M-0Y-06M-06M-0GM. \\
Sids-12 & BUC// 7c/ Ald/5/ Maya 74/ On/ 1160.147/3/ BB/ G11/4/ Chat"S" /6/ Maya/ vu1 // Cmh \\
Sids-13 & ALmaz 19= Kauz "S" // Tsi /snb"S" ICW 94-0375- 4AP- 2AP-030AP-) APS- 2AP- 0APS- 050AP- 0AP- 0SD. \\
Sids-14 & SW8488*2/ KUKUNA- CGSS01Y00081T-099M-099Y-099M-099B-9Y-0B-0SD. \\
Giza-168 & MIL/BUC// Seri CM93046-8M-0Y-0M-2Y-0M \\
Giza-171 & Gemmeiza-9 / Sakha-93 \\
Misr-1 & Oasis/skauz//4* BCN/3/2* Pastor CMss 00Y01881T-050M-030Y-030M-030WGY-33M- 0Y-0S. \\
Misr-2 & SKAUZ/ BAV 92. CMss 96 M03611S- 1M- 0105Y-010M-010SY- 8M- 0Y-0S. \\
Sahka-93 & Sakha 92TR81032 S8871-1S-2S-1S-0S. \\
Gemmeiza-9 & Ald"S"/ Huac"S" // CMH 74A.630/ 5x CGM 4583-5GM- 1GM-0GM. \\
\hline
\end{tabular}


Table 2: Designated names, source, and chromosomal positions of identified resistance genes to powdery mildew used in this study.

\begin{tabular}{|c|c|c|c|c|}
\hline Host differential & Accession number & Resistance gene & Position & Source \\
\hline Axminster / 8*Ccy & Cl 14114 & Pm1a & $7 A L$ & T. aestivum \\
\hline Ulka / 8* Cc & Cl 14118 & Pm2 & $5 D S$ & T.aestivum/ A. tauschii \\
\hline Asosan / 8* Cc & Cl 14120 & Pm3a & TAS & - \\
\hline Chull / 8* Cc & Cl 14121 & Pm3b & $1 \mathrm{AS}$ & T. aestivum \\
\hline Sonora / 8* Cc & Cl14122 & Pm3c & $1 \mathrm{AS}$ & T. aestivum \\
\hline Ralle & None & $P m 3 d$ & $1 \mathrm{AS}$ & T. aestivum \\
\hline Pm3f & Cl15888 & Pm3f & $1 \mathrm{AS}$ & T. aestivum \\
\hline Pm4a & Cl14124 & Pm4a & $2 A L$ & T. dicoccum \\
\hline Ronos & None & Pm4b & $2 A L$ & T. carthlicum \\
\hline Pm5a & Cl14125 & Pm5a & $7 B L$ & T. aestivum \\
\hline Coker747 & None & Pm6 & $2 B L$ & T. timopheevii \\
\hline Transec & None & Pm7 & $4 B S .4 B L-2 R I$ & S. cereale \\
\hline Kavkaz & PI 361879 & Pm8 & $1 R S .1 B L$ & S. cereale \\
\hline N14 & None & Pm9 & $7 A$ & T. aestivum \\
\hline Wembley & None & Pm12 & $6 B s$ & A. speltoides \\
\hline Pm 16 & None & $P m 16$ & $4 A$ & T. dicoccoides \\
\hline Amigo & None & Pm17 & 1RS.1AL & S. cereale \\
\hline Pm 24 & None & Pm24 & 1DS & T. aestivum \\
\hline NC96BGTD3 & None & Pm35 & $5 \mathrm{DL}$ & A. tauschii \\
\hline 5-BIL29(durum) & None & Pm36 & $5 B \mathrm{BL}$ & T. dicoccoides \\
\hline NC99BGTAG11 & None & Pm37 & $7 A L$ & T. timopheevii \\
\hline Chancellor & Cl12333 & None & & \\
\hline
\end{tabular}

\section{Disease assessments}

Seedlings of each cultivar per line were inoculated 10 days after emergence by shaking conidia of the fungus from infected plants onto their leaves. The inoculum source originated from field grown plants infected with the fungus collected from different locations and multiplied on Morocco plants under controlled green house at Gemmeiza Research Station, Gharbya Governorate in 2013 and 2014 growing seasons. Disease response was recorded 8 days after inoculation according the scale used by Leath and Heun (1990). In this scale; $0=$ immune, $1-3=$ resistant reaction, 4 - $6=$ intermediate reaction, 7 - 9 susceptible reaction. Efficacy \% of Pm gene resistance was calculated according to the following according to Samborsky and Dyck (1976) as follow:

Efficacy $\%$ of Pm-gene $=\frac{\text { No. of resistant genes }}{\text { Total No. of the tested genes }} \times 100$

\section{DNA extraction}

Total DNA of each wheat cultivar and 3 monogenic line designated in Table 3 was extracted from $200 \mathrm{mg}$ leaf fresh leaf tissue was ground in liquid nitrogen with a mortar and pestle and subsequently DNA extraction accomplished using the Invisorb ${ }^{\circledR}$ Spin Plant Mini Kit (STRATEC Molecular, Germany) for purification for the DNA, according to manufacturer's instructions.

\section{PCR amplification conditions}

Four specific microsatellite (SSR) markers were screened in order to detect the Pm24, Pm35 and Pm37 genes in 13 common bread wheat cultivars grown in Egypt. These markers were Xgwm 337 SSR (Pm24), Xcfd7 SSR (Pm35) and Xgwm332, Xwmc 790 (Pm37) listed in Table 4. Amplification of powdery mildew 
monogenic lines region was conducted in an automated thermal cycler $\left(\mathrm{C} 1000^{\mathrm{TM}}\right.$ Thermal Cycler, Bio-RAD) using the primers and conditions listed in Tables 4 and 5 with one pre-denaturation cycle at $94{ }^{\circ} \mathrm{C}$ for 3 min. Each PCR mixture was $25 \mu 1$ with the following composition; $1 \mu 1$ of $25 \mathrm{ng}$ nucleic acid, $1 \mu \mathrm{l}$ of each primer (10 pmol), $12.5 \mu \mathrm{l}$ of GoTag ${ }^{\circledR}$ Colorless Master Mix (Promega Corporation, USA) and $9.5 \mu 1$ of Nuclease free water (Promega). PCR products (15 $\mu 1)$ were analyzed by electrophoresis in a $1.5 \%$ agarose gel, stained with ethidium bromide $(7.0 \mu \mathrm{g} / 50 \mathrm{ml})$ and DNA bands were visualized using a UV transilluminator and photographed.

\section{RESULTS AND DISCUSSION}

\section{Disease assessment of powdery mildew}

Data in Table 6 reveal the efficacy percentage of $21 \mathrm{Pm}$-genes for resistance against 42 isolates of pathotypes of $B$. graminis tritici. However, the genes Pm2, Pm6, Pm12, Pm16, Pm24, Pm35, Pm 36 and Pm 37 have remained completely effective for all isolates $(100 \%$ efficacy). However, the genes Pm3b, Pm4b and Pm17 were completely effective in 2013 only and showed intermediate efficacy in 2014. The genes $P m 1$ a, $P m 3$ a, $P m 3$ c, $P m 3$ d, $P m 3$ f, $P m 4$ a, $P m 5$ a, $P m$ 7, $P m 8$ and $P m 9$ showed fluctuated efficacy, which ranged from 25.00 to
$87.50 \%$ in 2013 season and from 38.23 to $97.05 \%$ in 2014 season. It could be recorded that the variety Chancellor showed 0.00 efficacy over the two seasons. All the Egyptian bread wheat cultivars showed susceptible responses ranged from $7-8$ when tested to the 52 isolates of powdery mildew.

\section{Microsatellite markers}

Four SSR diagnostic markers which linked with resistance genes of $P m 24,35$ and 37 were used in this study. The diagnostic marker Xgwm 337 linked with Pm24 amplified fragment of $200 \mathrm{bp}$ in the control Pm24 and was absent in all 13 Egyptian cultivars tested (Figure 1). Data in Figure 2 shows the fragment profile of the PCR amplifications of the SSR locus Xcfd7 (251 bp) in the control Pm35 and indicates the absence of Pm35 in all 13 Egyptian bread wheat cultivars. For detection of Pm37, two primers Xgwm332 and Xwmc 790 linked to resistance gene were used. The two primers amplified fragments of $193 \mathrm{bp}($ Xgwm332) and $76 \mathrm{bp}$ for $(X w m c 790)$ in the control Pm37 and were absent in the Egyptian bread wheat cultivars (Figures 3 and 4).

Molecular identification of specific DNA sequences can be used to identify the presence or absence of wheat powdery mildew (Pm) genes in wheat cultivars, (Chen and Chelkowski, 1999). Molecular marker techniques used for identification

Table 3: Designated names, source, and chromosomal positions of identified resistance genes to powdery mildew used in this study.

\begin{tabular}{ccccc}
\hline Pm genes & Cultivar/line & Source & Position & Reference \\
\hline Pm24 & Pm24 & T. aestivum & 1DS & Huang et al., 2000 \\
Pm35 & NC96NGTD3-Ab & A. tauschii & 5DL & Miranda et al., 2007 \\
Pm37 & NC96NGTAG11-Ab & T. timopheevii & 7AL & Perugini et al., 2008 \\
\hline
\end{tabular}

Table 4: Powdery mildew genes, primers, their sequence and size of amplified fragment used in this study.

\begin{tabular}{|c|c|c|c|c|}
\hline Gene & Primer & Sequence & $\begin{array}{c}\text { Size of amplified } \\
\text { marker fragment (bp) }\end{array}$ & Reference \\
\hline$P m 24$ & $\begin{array}{l}\text { Xgwm } 337 \\
\text { SSR }\end{array}$ & $\begin{array}{l}\text { F 5' CCTCTTCCTCCCTCACTTAGC 3' } \\
\text { R 5' T CTAACTGGCCTTTGCC 3' }\end{array}$ & $200 \mathrm{bp}$ & Huang et al., 2000 \\
\hline Pm35 & $X c f d 7$ SSR & $\begin{array}{l}\text { F 5' AGCTACCAGCCTAGCAGCAG 3' } \\
\text { R 5' TCAGACACGTCTCCTGAAAA 3' }\end{array}$ & $251 \mathrm{bp}$ & Miranda et al., 2007 \\
\hline \multirow[t]{2}{*}{ Pm37 } & $\begin{array}{l}\text { Xgwm332 } \\
\text { SSR }\end{array}$ & $\begin{array}{l}\text { F 5' AGCCAGCAAGTCACCAAAAC 3' } \\
\text { R5' AGTGCTGGAAAGAGTGAAGC 3' }\end{array}$ & $193 \mathrm{~b}$ & Perugini et al., 2008 \\
\hline & $\begin{array}{l}\text { Xwmc } 790 \\
\text { SSR }\end{array}$ & $\begin{array}{l}\text { F5'AATTAAGATAGACCGTCCATATCATCCA3' } \\
\text { R 5' CGACAACGTACGCGCC 3' }\end{array}$ & $76 \mathrm{bp}$ & \\
\hline
\end{tabular}


and confirmation of $P m$ genes to powdery mildew include Simple Sequence Repeats (SSR) known as microsatellite. It remains one of the most popular markers to-date and the latest designated powdery mildew resistant genes; Pm46 (Gao et al., 2012), Pm47 (Xiao et al., 2013), Pm49 (Piarulli et al., 2012) and Pm50 (Mohler et al., 2013) have been identified and mapped using this technique. Several other genes including $P m$ e,$P m 5$ e, $P m 24$ a, Pm24b, Pm27, Pm30, Pm31, Pm36, Pm40, Pm42, $P m 43$ and $P m 45$ were also located and mapped using microsatellite or Simple Sequence Repeat (SSR) markers.

Table 5: Cycle conditions of the used primers.

\begin{tabular}{|c|c|}
\hline$P m$ gene & Conditions \\
\hline Pm24 & $\begin{array}{l}1 \text { cycle of } 3 \text { min at } 95^{\circ} \mathrm{C} \text {, followed by } 35 \text { cycles of } 30 \mathrm{sec} \text {. at } 95^{\circ} \mathrm{C}, 20 \text { sec at } 55^{\circ} \mathrm{C} \text {, and } 30 \mathrm{sec} \text {. at } \\
72^{\circ} \mathrm{C} \text {, and finishing with } 10 \text { min incubation at } 72^{\circ} \mathrm{C} \text {. }\end{array}$ \\
\hline Pm35 & $\begin{array}{l}1 \text { cycle of } 5 \text { min at } 94{ }^{\circ} \mathrm{C} \text {, followed by } 34 \text { cycles of } 1 \text { min at } 94{ }^{\circ} \mathrm{C} \text {, } 30 \mathrm{sec} \text {. at } 56^{\circ} \mathrm{C} \text {, and } 1 \mathrm{~min} \text { at } \\
72^{\circ} \mathrm{C} \text {, and finishing with } 10 \text { min incubation at } 72^{\circ} \mathrm{C} \text {. }\end{array}$ \\
\hline Pm37 & $\begin{array}{l}1 \text { cycle of } 3 \text { min at } 94{ }^{\circ} \mathrm{C} \text {, followed by } 40 \text { cycles of } 1 \text { min at } 94{ }^{\circ} \mathrm{C}, 1 \text { min at } 54{ }^{\circ} \mathrm{C} \text {, and } 2 \text { min at } \\
72^{\circ} \mathrm{C} \text {, and finishing with } 10 \text { min incubation at } 72^{\circ} \mathrm{C} \text {. }\end{array}$ \\
\hline Pm37 & $\begin{array}{l}1 \text { cycle of } 3 \text { min at } 95^{\circ} \mathrm{C} \text {, followed by } 40 \text { cycles of } 45 \mathrm{sec} \text { at } 94^{\circ} \mathrm{C}, 45 \mathrm{sec} \text { at } 55^{\circ} \mathrm{C} \text {, and } 1 \mathrm{~min} \text { at } \\
72^{\circ} \mathrm{C} \text {, and finishing with } 10 \text { min incubation at } 72^{\circ} \mathrm{C} \text {. }\end{array}$ \\
\hline
\end{tabular}

Table 6: Gene efficacy percentage of $21 \mathrm{Pm}$ genes to 8 and 34 isolates of powdery mildew at seedling stage and mean disease response of 13 Egyptian bread wheat cultivars in 2013 and 2014 seasons.

\begin{tabular}{|c|c|c|c|c|c|c|c|c|}
\hline \multirow{3}{*}{ Pm gene } & \multicolumn{6}{|c|}{ Gene efficacy percentage in } & \multirow{2}{*}{\multicolumn{2}{|c|}{ Mean disease response }} \\
\hline & \multicolumn{3}{|c|}{2013} & \multicolumn{3}{|c|}{2014} & & \\
\hline & *S & ${ }^{* *} \mathrm{R}$ & Efficacy\% & ${ }^{*} \mathrm{~S}$ & ${ }^{*} \mathrm{R}$ & Efficacy\% & Cultivar & $\begin{array}{l}\text { Disease } \\
\text { response }\end{array}$ \\
\hline $1 a$ & 5 & 3 & 37.50 & 22 & 12 & 35.29 & Gemmeiza-7 & $8^{* \star \star}$ \\
\hline 2 & 0 & 8 & 100 & 0 & 34 & 100 & Gemmeiza-10 & 7 \\
\hline $3 a$ & 1 & 7 & 87.50 & 19 & 15 & 44.11 & Gemmeiza-11 & 8 \\
\hline $3 b$ & 0 & 8 & 100 & 13 & 21 & 61.76 & Gemmeiza-12 & 8 \\
\hline $3 c$ & 1 & 7 & 87.50 & 22 & 12 & 35.29 & Sids- 12 & 6 \\
\hline $3 d$ & 1 & 7 & 87.50 & 1 & 33 & 97.05 & Sids-13 & 9 \\
\hline $3 f$ & 5 & 3 & 37.50 & 13 & 21 & 61.76 & Sids-14 & 9 \\
\hline $4 a$ & 3 & 5 & 62.50 & 10 & 24 & 70.58 & Giza-168 & 8 \\
\hline $4 b$ & 0 & 8 & 100 & 6 & 28 & 82.35 & Giza-171 & 8 \\
\hline $5 a$ & 1 & 7 & 87.50 & 21 & 13 & 38.23 & Misr-1 & 8 \\
\hline 6 & 0 & 8 & 100 & 0 & 34 & 100 & Misr-2 & 8 \\
\hline 7 & 4 & 4 & 50 & 21 & 13 & 38.23 & Sahka-93 & 7 \\
\hline 8 & 6 & 2 & 25 & 18 & 16 & 47.58 & & \\
\hline 9 & 6 & 2 & 25 & 19 & 15 & 44.11 & & \\
\hline 12 & 0 & 8 & 100 & 0 & 34 & 100 & & \\
\hline 16 & 0 & 8 & 100 & 0 & 34 & 100 & & \\
\hline 17 & 0 & 8 & 100 & 21 & 13 & 38.23 & & \\
\hline 24 & 0 & 8 & 100 & 0 & 34 & 100 & & \\
\hline
\end{tabular}


Table 6: Continuation.

\begin{tabular}{ccccccc}
\hline 35 & 0 & 8 & 100 & 0 & 34 & 100 \\
36 & 0 & 8 & 100 & 0 & 34 & 100 \\
37 & 0 & 8 & 100 & 0 & 34 & 100 \\
Chancellor & 8 & 0 & 0.00 & 34 & 0 & 0.00 \\
\hline
\end{tabular}

${ }^{*}$ S: Susceptible; ${ }^{* *}$ R: Resistance; ${ }^{* *} 7-9$ : Susceptible response.

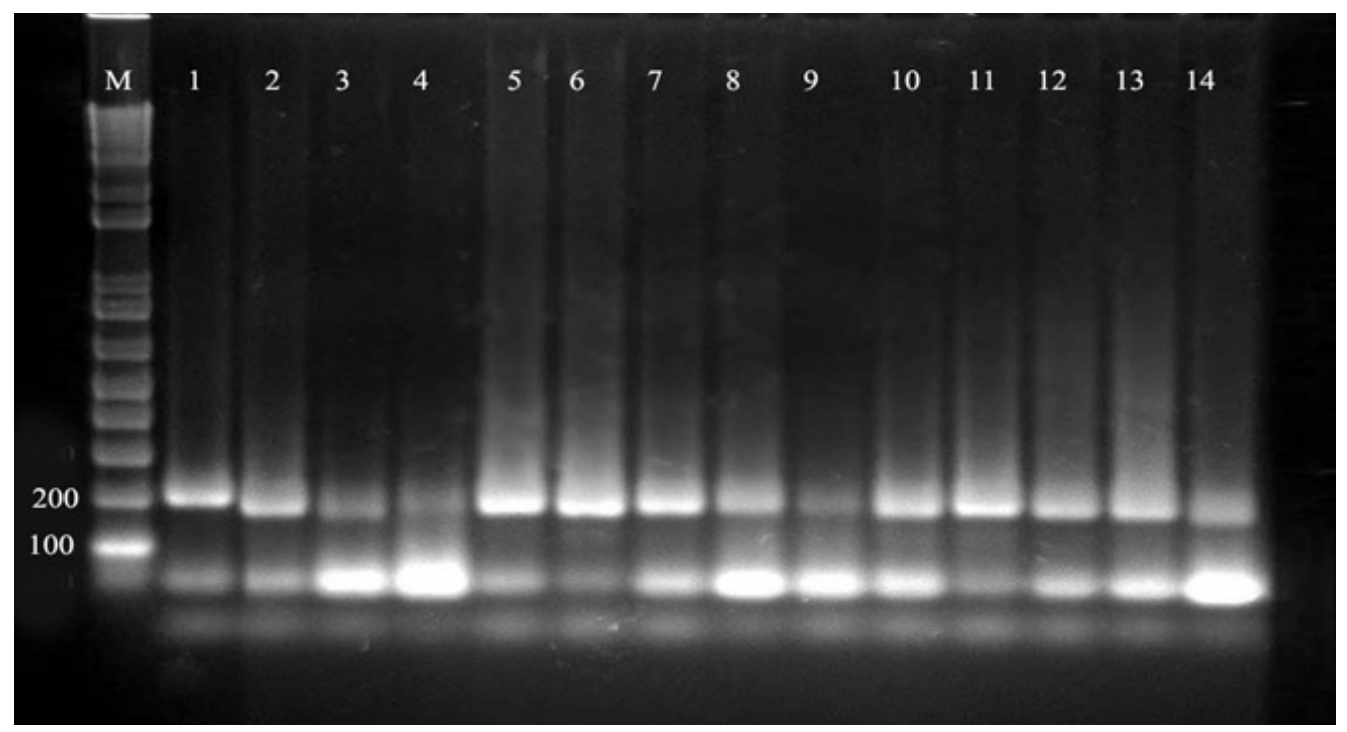

Figure 1: Fragment profile of the PCR amplifications of SSR Xgwm337 locus (200 bp) in Pm24 and 13 Egyptian cultivars. M: 100bp DNA ladder RTU (Gene Direx). 1: Pm24 gene, 2: Gemmeiza-7, 3: Gemmeiza-10, 4: Gemmeiza-11, 5: Gemmeiza-12, 6: sids-12, 7: Sids-13, 8: Sids-14, 9: Giza-168, 10: Giza-171, 11: Misr-1, 12: Misr-2, 13: Sahka93.

The obtained data reveals that out of twenty-one $\mathrm{Pm}$ lines of wheat evaluated to 42 individual powdery mildew isolates, $P m$ genes $P m 2$, $P m 6, P m 12, P m 16, P m 24, P m 35$, $P m 36$ and $P m 37$ were resistant at seedling stage and also, at adult stage. Only four DNA specific SSR markers i.e. Xgwm337, Xcfd7 linked to Pm24, Pm35 and Xgwm332, $X w m c 790$ linked to $P m 37$ resistance genes were selected to detect these genes in 13 Egyptian common bread wheat cultivars, while all the tested Egyptian wheat cultivars showed susceptible responses at the both stages. This is first time to evaluate $P m$ genes in Egypt either at seedling or adult stages. The four SSR markers used in this study confirmed the absence of Pm24, Pm35 and Pm37 in the Egyptian bread wheat cultivars. SSR markers amplification products of the tested cultivars showed alleles to each resistance gene with different sizes. For detection of $P m 24$, Pm35 and Pm37 in Egyptian cultivars showed alleles with smaller size than in monogenic line. The results of our study are in agreement with the work of Mirinda et al. (2007). They found that when Xcfd7 microsatellite marker tested in the F2 progeny, a $251 \mathrm{bp}$ fragment was associated with the resistant NCD3 (Pm35) allele and a 240 bp band was associated with the susceptible allele. Also, similar results were obtained by Blanco et al. (2008). In their study, the EST-SSR BJ261635 primer linked to Pm36 amplified two co-migrating bands (236 and 244bp) and one band in the susceptible plants (237bp). Two primers linked to $P m 37$ showed alleles with larger sizes than in the monogenic line. These alleles may be linked to susceptibility since the difference between resistance and susceptibility is base pair change (Lawrence et al., 1994). Also, Perugini et al. (2008) stated Simple sequence repeat (SSR) markers Xgwm332 and Xwmc 790 were located $0.5 \mathrm{cM}$ proximal and distal, respectively, to $P m 37$. Differences within genes or between genes in the DNA strand as long as unique sequences varying between the 
plants of interest are referred to as polymorphisms. The use of resistant cultivars has proven to be an effective and environmentally safe strategy for controlling wheat fungal pathogens and eliminating or reducing the use of fungicides. Molecular markers tightly linked to disease resistance genes allow selection for resistance without the need to perform disease tests and even in the absence of the pathogen and that will facilitate combining more than one effective disease resistance gene in one genotype (Blanco et al., 2008; Langridge et al., 2001; Tanksley et al., 1989).

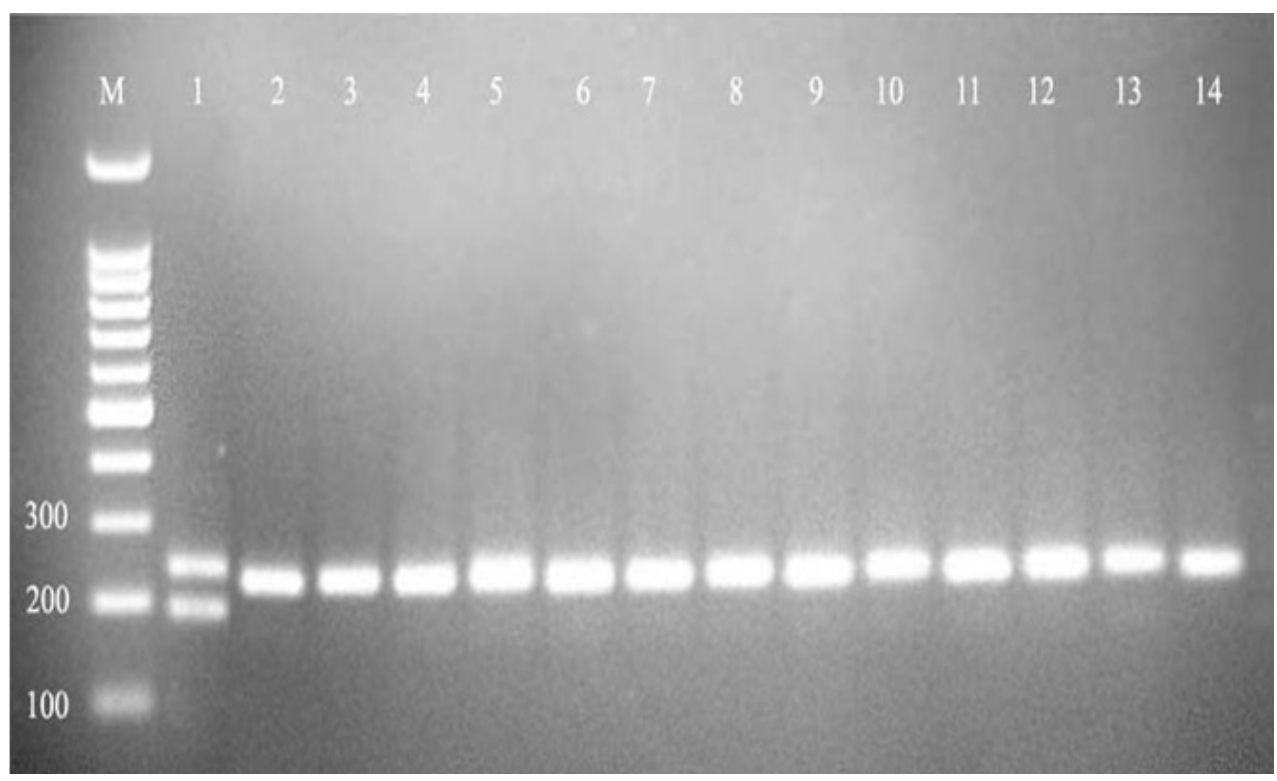

Figure 2: Fragment profile of the PCR amplification of SSR loci Xcfd7 (251 bp) in Pm 35 and 13 Egyptian cultivars. M.: 100 bp DNA ladder RTU (Gene Direx). 1: Pm35 gene, 2: Gemmeiza-7, 3: Gemmeiza-10, 4: Gemmeiza-11, 5: Gemmeiza-12, 6: sids-12, 7: Sids-13, 8: Sids-14, 9: Giza-168, 10: Giza-171, 11: Misr-1, 12: Misr-2, 13:Gemmeiza9.

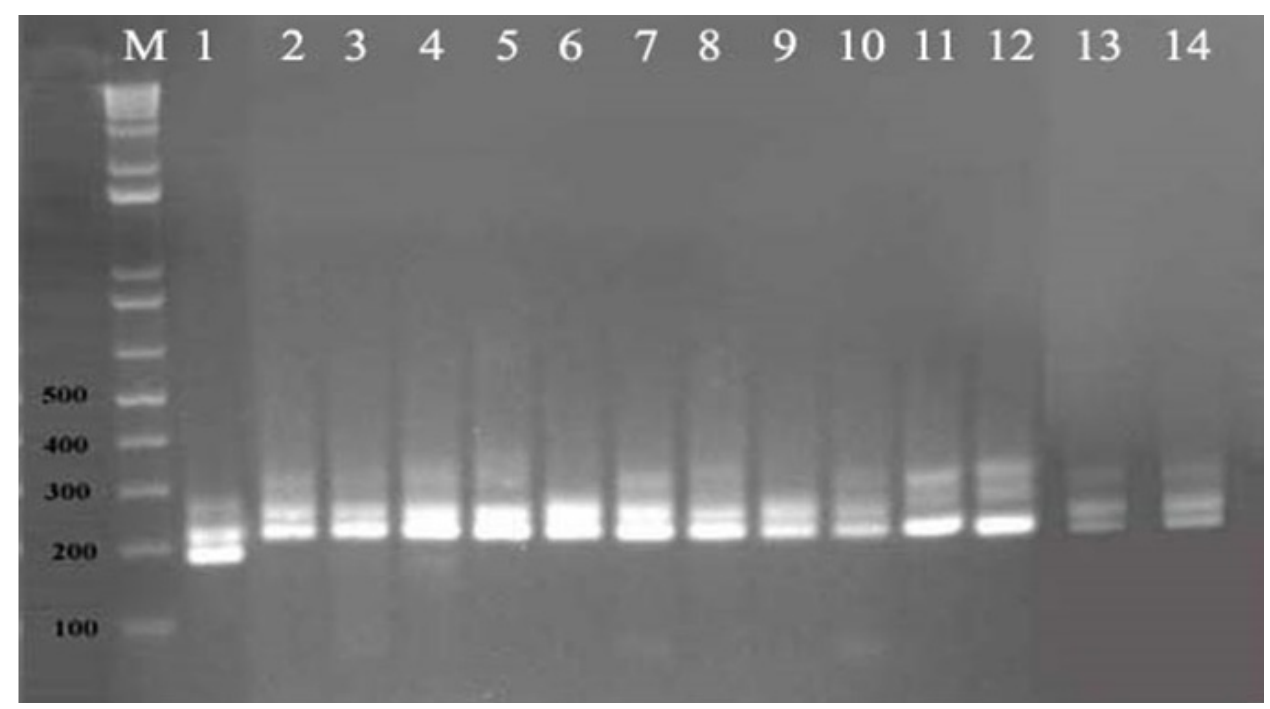

Figure 3: Fragment profile of the PCR amplification of SSR xgwm 332 locus (193 bp) in Pm37 and 13 Egyptian cultivars. M: 100bp DNA ladder RTU (Gene Direx). 1: Pm37 gene, 2: Gemmeiza-7, 3: Gemmeiza-10, 4: Gemmeiza-11, 5: Gemmeiza-12, 6: sids-12, 7: Sids-13, 8: Sids-14, 9: Giza-168, 10: Giza-171, 11: Misr-1, 12: Misr-2, 13: Sahka93. 


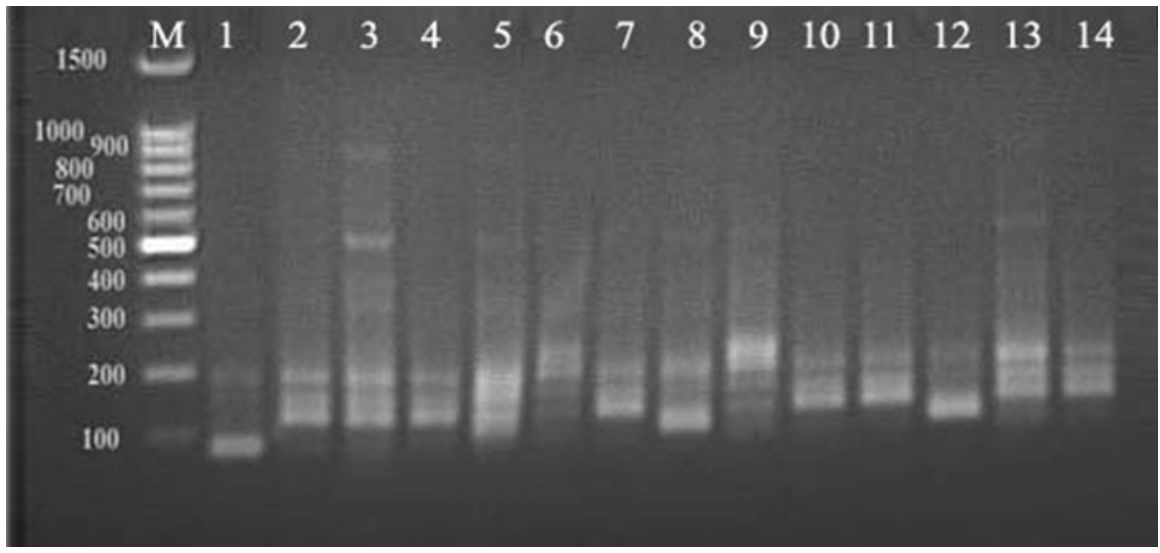

Figure 4: Shows the fragment profile of the PCR amplifications of SSR Xwmc790 locus (76 bp) in Pm37 and 13 Egyptian cultivars. M: 100 bp DNA ladder RTU (Gene Direx). 1: Pm37 gene, 2: Gemmeiza-7, 3: Gemmeiza-10, 4: Gemmeiza-11, 5: Gemmeiza-12, 6: sids-12, 7: Sids-13, 8: Sids-14, 9: Giza-168, 10: Giza-171, 11: Misr-1, 12: Misr-2, 13: Sahka93.

\section{CONCLUSIONS}

This study shows that $P m 24, P m 35$ and $P m 37$ are absent in the 13 tested Egyptian bread wheat cultivars. So, incorporating these resistance genes through wheat breeding program may lead to powdery mildew resistance genotypes with more durable resistance to the disease.

\section{ACKNOWLEDGEMENTS}

The authors would like to express their thanks to Prof. Dr. Christina Cowger, Small Grains Pathologist, USDA-ARS, Department of Plant Pathology, North Carolina State University for providing us with wheat powdery mildew differentials.

\section{REFERENCES}

BLANCO, A. et al. Molecular mapping of the novel powdery mildew resistance gene Pm36 introgressed from Triticum turgidum var. dicoccoides in durum wheat. Theoretical \& Applied Genetics, 11:417-425, 2008.

CHEN, Y.; CHELKOWSKI, J. Genes for resistance to wheat powdery mildew. Journal of Applied Genetics, 40:317334, 1999.

CHENG, S. et al. Genetic improvement of wheat powdery mildew resistance and construction of multi-lines. Journal of Triticeae Crops, 23:34-38, 2003.

COSTAMILAN, M. L. Variability of the wheat powdery mildew pathogen Blumeria graminis f. sp. tritici in the 2003 crop season. Fitopatologia Brasileira, 30:420-422, 2005.
EL-SHAMY, M. M. et al. Powdery mildew infection on some Egyptian bread wheat cultivars in related to environmental conditions. Journal of Agriculture Sciences, 3(4):363-372, 2012.

EVERTS, K. L.; LEATH, S. Effect of early season powdery mildew on development, survival, and yield contribution of tillers of winter wheat. Phytopathology, 82:12731278, 1992.

$\mathrm{GAO}, \mathrm{H}$. et al. Genetic analysis and molecular mapping of a new powdery mildew resistant gene Pm46 in common wheat. Theoretical \& Applied Genetics, 125(5):967-973, 2012.

$H E$, R. et al. Inheritance and mapping of powdery mildew resistance gene Pm43 introgressed from Thinopyrum intermedium into wheat. Theoretical \& Applied Genetics, 118:1173-1180, 2009.

HOSPITAL, F. Size of donor chromosome segments around introgressed loci and reduction of linkage drag in markerassisted backcross programs. Genetics, 158:1363-1379, 2001.

HUA, W. et al. Identification and molecular mapping of Pm42, a new recessive wheat powdery mildew resistant gene derived from wild emmer (Triticium turgidum var. dicoccoides). Theoretical \& Applied Genetics, 119:223230, 2009.

HUANG, L. S. et al. Continuous wavelet analysis for diagnosing stress characteristics of leaf powdery mildew. International Journal of Agriculture \& Biology, 15:34-40, 2013. 
HUANG, X. Q. et al. Molecular mapping of the wheat powdery mildew resistance gene Pm24 and marker validation for molecular breeding. Theoretical \& Applied Genetics, 101:407-414, 2000.

LANGRIDGE, P. et al. Trends in genetics and genome analyses in wheat: a review. Australian Journal of Agriculture Research, 52:1043-1077, 2001.

LAWRENCE, G. J. et al. Plant resistance to rusts and mildews: genetic control and possible mechanisms. Trends in Microbiology, 2(8):263-270, 1994.

LEATH, S.; HEUN, M. Identification of powdery mildew resistance genes in cultivars of soft red winter wheat. Plant Diseases, 74:747-752, 1990.

LI, G.; FANG, T.; ZHANG, H. Molecular identification of a new powdery mildew resistance gene Pm41 on chromosome $3 \mathrm{BL}$ derived from wild emmer (Triticum turgidum var. dicoccoides). Theoretical \& Applied Genetics, 119: 531 539, 2009.

LUO, P. G. et al. Characterization and chromosomal location of Pm40 in common wheat: a new gene for resistance to powdery mildew derives from Elytrigia intermedium. Theoretical \& Applied Genetics, 18:1059-1064, 2009.

MAXWELL, J. J. et al. MIAG12: a Triticum timopheevii-derived powdery mildew resistance gene in common wheat on chromosome 7AL. Theoretical \& Applied Genetics, 119:1489-1495, 2009.

MCINTOSH, R. A.; YAMAZAKI, Y.; DUBCOVSKY, J. Catalogue of gene symbols for wheat. 2008. Available in: <http:// wheat.pw.usda.gov/GG2/Triticum/wgc/2008/>. Access in: 17 March, 2010.

MIRANDA, L. M. et al. Chromosomal location of Pm35, a novel Aegilops tauschii derived from powdery mildew resistance gene introgressed into common wheat (Triticum aestivum L.). Theoretical \& Applied Genetics, 114:1451-1456, 2007.

MOHLER, V. et al. Pm50: a new powdery mildew resistance gene in common wheat derived from cultivated emmer. Journal of Applied Genetic, 54(3):259-263, 2013.

MURPHY, J. P.; NAVARRO, R. A.; LEATH, S. Registration of NC99BGTAG11 wheat germplasm resistant to powdery mildew. Crop Science, 42:1382, 2002.

NAVARRO, R. A. et al. Registration of NC97BGTAB9 and NC97BGTAB10 wheat germplasm lines resistant to powdery mildew. Crop Science, 40:1508-1509, 2000.

PERUGINI, L. D. et al. Pm37, a new broadly effective powdery mildew resistance gene from Triticum timopheevii. Theoretical \& Applied Genetics, 116:417-425, 2008.

PIARULLI, L. et al. Molecular identification of a new powdery mildew resistance gene on chromosome 2BS from Triticum turgidum ssp. dicoccum. Plant Science, 196:101-106, 2012.

SAMBORSKY, D. J.; DYCK, P. L. Inheritance of virulence in Puccinia reconditaon six back cross lines of wheat with single genes for resistance to leaf rust. Canadian Journal of Botany, 54:1666-1671, 1976.

SANG, D. et al. The molecular identification of powdery mildew resistance genes in the cultivars in Henan Province and application of molecular marker-assisted breeding. Acta Agriculturae Boreali-Sinica, 21:86-89, 2006.

TANKSLEY, S. D. et al. RFLP mapping in plant breeding: new tools for an old science. Biotechnology, 7:257-264, 1989.

$\mathrm{XIAO}$, M. et al. Identification of the gene Pm47 on chromosome 7BS conferring resistance to powdery mildew in the Chinese wheat landrace Hongyanglazi. Theoretical and Applied Genetics, 126 (5):1397-1403, 2013. 